\title{
ABSTRAK \\ GAMBARAN TINGKAT PENGETAHUAN MAHASISWA TENTANG PEMERIKSAAN PAYUDARA SENDIRI DI ATAMBUA
}

\author{
Aurelia Jeni Kariani Nahak ${ }^{(1)}$ \\ Pius A.L. Berek ${ }^{(2)}$ \\ Maria Fatimah W.A. Fouk ${ }^{(3)}$ \\ 1) 2) 3) Prodi Keperawatan Universitas Timor Kampus Atambua, Jln Wehor Kabuna Haliwen, Atambua, \\ Nusa Tenggara Timur. Post: 85711. Email: francis_domin2012@yahoo.com
}

SADARI adalah pemeriksaan payudara sendiri untuk mendeteksi dini adanya kanker payudara. Tujuan dari penelitian ini adalah untuk mengetahui tingkat pengetahuan mahasiswa tentang pemeriksaan payudara sendiri dalam hal Tahu (Know), Memahami (Comprehension), penerapan (aplication) dan analisis (analysis) di Prodi Keperawatan Universitas Timor Kampus Atambua. Penelitian ini menggunakan pendekatan kuantitatif dengan metode deskriptif murni. Sampel yang diteliti yaitu 92 orang dengan menggunakan metode simple random sampling. Hasil penelitian ditemukan 97\% responden berpengetahuan "baik", dan masih ada 3\% yang memiliki pengetahuan "cukup". Hal ini menunjukan bahwa tingkat pengetahuan mahasiswa prodi keperawatan universitas timor kampus atambua sangat tinggi. Setelah mahasiswa mengetahui tentang pemeriksaan payudara sendiri ini, diharapkan mereka akan melakukan pemeriksaan payudara sendiri secara rutin untuk menghindari atau mencegah secara dini terjadi kanker payudara dikemudian hari.

\section{Kata Kunci : Sadari, Tingkat Pengetahuan.}

\section{ABSTRAC \\ DESCRIPTION ABOUT STUDENT'S LEVEL OF KNOWLEDGE OF BREAST SELF-EXAMINATION IN ATAMBUA}

\author{
Aurelia Jeni Kariani Nahak ${ }^{(1)}$ \\ Pius A.L. Berek ${ }^{(2)}$ \\ Maria Fatimah W.A. Fouk ${ }^{(3)}$ \\ 1) 2) 3) Nursing Program of University of Timor, Atambua Campus. Jl. Wehor Kabuna Haliwen, \\ Atambua, East Nusa Tenggara. Post: 85711. Email: francis_domin2012@yahoo.com
}

SADARI is breast self-examination for early detection of breast cancer. The purpose of this study is to determine the level of knowledge of students about breast self-examination in terms of Knowing Comprehension, application, and analysis at nursing Program of University of Timor. This research uses quantitative approach with pure descriptive method. The samples studied were 92 people using simple random sampling method. The results show that $97 \%$ respondents are good knowledge and exist also 3\% of respondents are enough of knowledge about sadari. This confirms that the level of knowledge of students at Nursing Program Study University of Timor Atambua Collageis very high. The students are known breast self-examination they are expected to do that regularly to prevent early breast cancer.

\section{Keywords : Breast Self Examination, level of knowledge.}




\section{PENDAHULUAN}

Remaja adalah periode transisi antara masa kanak-kanak dan masa dewasa. (Hokenberry, 2009 dalam Untari, 2012). Masa remaja terdiri atas tiga subfase yang jelas, yaitu : masa remaja awal (usia 11 sampai 14 tahun), masa remaja pertengahan (usia 15 sampai 17 tahun), masa remaja akhir usia 18 sampai 20 tahun) remaja atau adolesens adalah periode perkembangan selama individu mengalami perubahan dari masa kanak-kanak menuju masa dewasa biasanya antara usia 13 sampai 20 tahun. Karena remaja adalah masa remaja menuju pematangan diri maka pada tahap inilah terjadi pematangan fisik, kognitif, sosial, dan emosional yang cepat.

Payudara adalah sepasang kelenjar mamae yang terletak diantara tulang iga kedua dan keenam (Poter \& Perry, 2005). Payudara adalah organ berhubungan dengan reproduksi dan seksualitas wanita sehingga tingkat ansietas tinggi mungkin diekspresikan oleh klien saat pemeriksaan payudara (Muttaqin,2012). SADARI merupakan suatu teknik penyeringan yang sederhana dan baik untuk penyakit payudara (Wardhani, 2017).

\section{Menurut}

World

HealthOrganization

(WHO)

memprediksikan bahwa ditahun 2020 penyakit tidak menular akan menjadi penyebab $73 \%$ kematian di dunia. Indonesia sebagai salah satu negara di Asia juga tidak luput dari serangan penyakit ini berdasarkan pusat data dan informasi kementerian kesehatan tahun 2015 estimasi jumlah kasus baru dan jumlah kematian akibat kanker payudara di Rumah sakit (RS) Kanker Dharmais tahun 2010-2013 terus mengalami peningkatan yang signifikan setiap tahunnya, dimana pada tahun 2010 terdapat 711 kasus baru dengan 93 kematian akibat kanker payudara, pada tahun 2011 meningkat menjadi 769 kasus baru dengan 120 kematian akibat kanker payudara, dan pada tahun 2012 meningkat menjadi 809 kasus baru dengan 150 kematian akibat kanker payudara, sedangkan pada tahun 2013 meningkat menjadi 819 kasus baru dengan kematian 217. Data ini menjadikan kanker payudara menjadi kanker dengan penderita paling banyak dan penyebab kematian paling banyak di Indonesia. (Harnianti, 2012). Penyebab tingginya angka kematian kanker payudara adalah karena pasien datang dalam kondisi stadium lanjut. (Untari, 2012).

Berdasarkan uraian latar belakang diatas maka penulis tertarik untuk melakukan penelitian dengan judul

"Bagaimana Gambaran Tingkat Pengetahuan Mahasiswa Tentang Pemeriksaan Payudara Sendiri” Di Prodi Keperawatan Universitas Timor Kampus Atambua”.

\section{TINJAUAN PUSTAKA}

\section{PENGERTIAN}

Konsep mengenai pengetahuan sangat erat kaitannya dengan konsep perilaku dan sikap (Notoatmodjo, 2007 dalam Untari,2012) menyatakan bahwa perilaku adalah semua kegiatan atau aktivitas manusia baik yang dapat diamati secara langsung maupun yang tidak dapat diamati oleh pihak luar. Seorang ahli psikologi merumuskan bahwa perilaku merupakan respon atau reaksi seorang terhadap stimulus (rangsangan dari luar) oleh karena perilaku terjadi melalui proses adanya stimulus terhadap organisme tersebut 
memberi respon, maka teori skiner disebut teori stimulus-organismerespon (Skiner 1998 dalam Untari,2012.)

Sikap adalah respon tertutup seseorang terhadap suatu stimulus atau objek, dimana manifestasinya tidak dapat langsung dilihat tetapi hanya dapat ditafsirkan terlebih dahulu dari perilaku yang tertutup tersebut. (Notoatmodjo,2007 dalam Untari, 2012).

Berdasarkan defenisi diatas maka dapat disimpulkan bahwa pengetahuan adalah hasil dari keingintahuan seseorang terhadap suatu objek tertentu dengan menggunakan panca indera yang dimiliki dan diperoleh melalui proses belajar baik didapat secara pendidikan formal ataupun informal dengan tujuan untuk menyelesaikan persoalan yang dihadapi. (Untari, 2012)

\section{TINGKAT PENGETAHUAN}

Menurut Notoatmodjo (2010) dalam Untari, secara garis besar pengetahuan dibagi dalam 6 tingkatan yaitu :

\section{Tahu(Know)}

Tahu diartikan sebagai kemampuan masyarakat mengingat atau recall (memanggil) kembali memori atau materi yang telah dipelajari berkaitan dengan pencegahan kanker payudara.

2. Memahami (Comprehension)

Dapat diartikan sebagai suatu keadaan dimana seseorang mampu menjelaskan dan menginterprestasikan dengan benar tentang objek yang diketahui misalnya orang yang memahami SADARI bukan hanya sekedar menjelaskan tetapi harus dapat memberikan contoh dan menyimpulkan.

3. Penerapan (Aplikation)

Aplikasi diartikan sebagai kemampuan untuk menggunakan materi yang telah dipelajari pada situasi atau kondisi yang sebenarnya. Misalnya seseorang yang telah paham tentang pemeriksaan payudara sendiri (SADARI) ia harus membuat perencanaan pencegahan kanker payudara ditempat ia tinggal atau dimana saja.

4. Analisis (Analysis)

Analisis adalah suatu kemampuan untuk menjabarkan atau memisahkan kemudian mencari hubungan antara komponen-komponen yang terdapat dalam suatu masalah atau objek yang diketahui indikasi bahwa pengetahuan seseorang itu sudah sampai pada tingkat analisis adalah apabila orang tersebut telah dapat membedakan atau memisahkan, mengelompokan membuat diagram (bagan) terhadap pengetahuan atau objek tersebut.

5. Sintesis (Synthesis)

Sintesis adalah suatu kemampuan seseorang untuk merangkung atau meletakkan dalam satu hubungan yang logis dari komponen-komponen pengetahuan yang dimiliki. Dengan kata lain sintesis adalah suatu kemampuan untuk menyususn formulasi baru dari formulasi-formulasi yang telah ada misalnya dapat membuat atau meningkat dengan kata-kata atau kalimat sendiri tentang hal-hal yang telah dibaca atau didengar, dan dapat membuat kesimpulan tentang artikel yang telah dibaca. 


\section{Evaluasi (Evaluation)}

Evaluasi berkaitan dengan kemampuan seseorang untuk melakukan pembenaran atau penilaian terhadap objek tertentu penilaian ini dengan sendirinya didasarkan pada suatu kriteria yang ditentukan sendiri tau normanorma yang berlaku.

\section{REMAJA}

Secara psikologi remaja adalah usia dimana individu berintegrasi dengan masyarakat dewasa masa dimana anak tidak lagi merasa dibawah tingkat orang-orang yang lebih tua melainkan berada dalam tingkat yang sama. Masa remaja dianggap terdiri atas tiga subfase yang jelas yaitu masa remaja awal (usia 1114 tahun), masa remaja pertengahan (usia 15-17 tahun), dan masa remaja akhir (usia 18-20 tahun). (Wong, 2009 dalam Untari, 2012). Menurut DEPKES RI (2005), masa remaja merupakan suatu proses tumbuh kembang yang berkesinambungan yang merupakan masa peralihan dari kanak-kanak kedewasa muda yang didalamnya terjadi perubahan emosi dan perubahan sosial.

Perubahan fisik dan Maturasi sosial pada remaja

Perubahan fisik terjadi dengan cepat pada adolesens. Maturasi seksual terjadi seiring perkembangan karakteristik seksual primer dan sekunder. Karakteristik primer berupa perubahan fisik dan hormonal yang penting untuk reproduksi, sedangkan karakteristik sekunder menunjukan penampilan eksternal yang berbeda antara laki-laki dan perempuan. Empat fokus utama perubahan fisik adalah : peningkatan kecepatan pertumbuhan skelet,otot dan visera, perubahan spesifik seks, seperti perubahan bahu dan leher pinggul, perubahan distribusi otot dan lemak, perkembangan sistem reproduksi dan karakteristik seks sekunder.

\section{PEMERIKSAAN SENDIRI (SADARI)}

\section{PAYUDARA}

Pengertian

SADARI adalah pemeriksaan payudara sendiri untuk mengetahui kemungkinan adanya kanker payudara atau benjolan yang memungkinkan adanya kanker payudara.

Midpro,edisi 1, 2013). Payudara adalah organ berhubungan dengan reproduksi dan seksulitas wanita sehingga tingkat ansietas tinggi mungkin diekspresikan oleh klien saat pemeriksaan

(Muttaqin,2012). Dari beberapa pengertian diatas, penulis menyimpulkan bahwa SADARI adalah pemeriksaan payudara sendiri untuk mendeteksi dini adanya kanker payudara.

Antomi Payudara

Anatomi tentang payudara dapat dijelaskan sesuai dengan gambar berikut:

Gambar 1 Anatomi Payudara

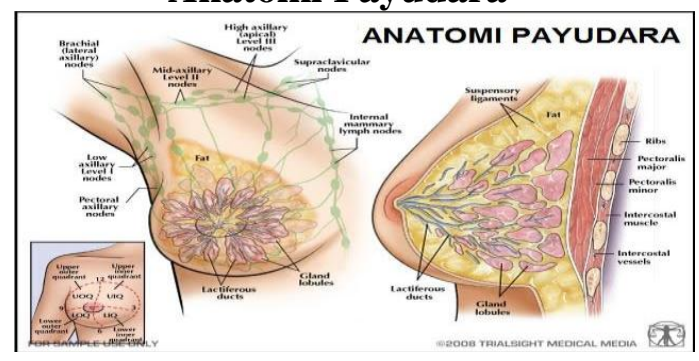

Jaringan payudara terntang dari sekitar iga kedua sampai keenam 
(bergantung pada postur). Perluasan kauda (ekor) jaringan kedalam aksila dapat menyebabkan rasa tidak nyaman pada masa nifas dini saat jaringan tersebut membengkak. Konstituen utama payudara adalah sel kelenjar disertai duktus terkait serta jaringan lemak dan jaringan ikat dalam jumlah bervariasi. Payudara dibagi menjadi bagian atau lobus oleh septum fibrosa, yang berjalan dari belakang puting payudara kearah otot pektoralis. Septum ini penting untuk melokalisasi infeksi, yang sering terlihat sebagai baji kulit merah meradang dipermukaan payudara. Masingmasing dari 15-20 lobus yang pisahkan oleh jaringan ikat, mengandung jaringan glandular yang tersusun sebagai suatu sistem duktus-alveolus. Sel sekretorik alveolus berkelompokkelompok seperti buah anggur disekitar sitem duktus yang bercabangcabang, yang menyatu membentuk ductus laktiferosa utama menuju puting payudara. Duktus laktiferosa melebar membentuk ampula atau sinus, tepat didasar puting payudara dan terbuka keeksterior melalui duktus ejektorius. Puting payudara dikelilingi olehareola, suatu daerah berpigmen yang ukuranya bervariasi, yang bertambah gelap saat hamil serta kaya akan pasokan pembuluh darah dan serat saraf sensorik. Disekitar puting payudara terdapat tuberkel montgomeri-kelenjar sebasea yang mengalami hipertrofi dan menjadi menonjol saat hamil, menghasilkan pelumas dan memberi perlindungan. Pemakaian sabun dalam jumlah besar dapat meningkatkan resiko kerusakan puting payudara, terutama kekeringan dan retak. Kepekaan puting payudara dan daerah disekitarnya sangat meningkat segera setelah persalinan, pengisapan menyebabkan influks impuls saraf aferen ke hipotalamus yang mengontrol laktasi dan perilaku ibu. (Monica Ester, 2006)

Langkah-langkah

pemeriksaan payudara sendiri

SADARI dilakukan dengan menggunakan jari telunjuk, jari tengah, dan jari manis, yang digerakkan secara bersamaan pada payudara yang dilakukan pemeriksaan.

Ada 6 langkah pemeriksaan payudara sendiri (SADARI) yaitu seperti tampak pada gambar berikut :

\section{Gambar 2}

Langkah - Langkah Sadari

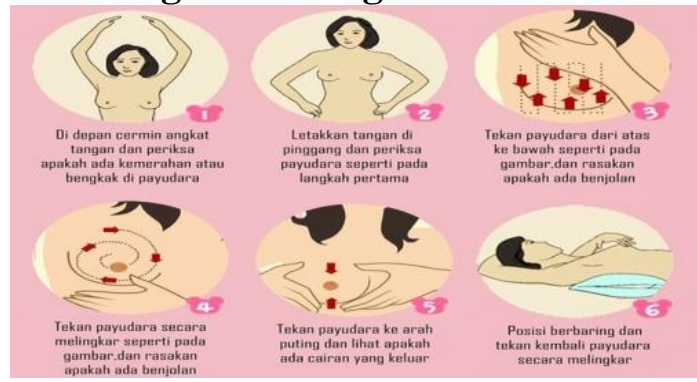

Sumber : Riskan, 2012.

Kesan awal dengan pemeriksaan payudara sendiri.

1. Langkah 1

1) Berdirilah didepan cermin

2) Periksa payudara terhadap segala sesuatu yang tidak lazim

3) Perhatikan adanya rabas dari puting susu, keriput, dimpung atau kulit mengelupas.

2. Langkah 2

1) Perhatikan dengan baik didepan cermin ketika anda melipat tangan anda dibelakang kepala anda dan menekan tangan anda kearah depan.

2) Perhatikan setiap perubahan kontur dari payudara anda.

3. Langkah 3 
1) Selanjutnya tekan tangan anda dengan kuat pada pinggang anda dan agak membungkuk kearah cermin sambil menarik bahu anda dan siku anda kearah depan.

2) Perhatikan setiap perubahan kontur payudara anda.

4. Langkah 4

1) Angkat lengan kiri anda

2) Gunakan tiga atau empat jari tangan kanan anda untuk meraba payudara kiri anda dengan kuat hati-hati dan menyeluruh

3) Mulailah pada tepi terluar tekan bagian datar dari jari tangan anda dalam lingkaran kecil bergerak melingkar dengan lambat disekitar payudara

4) Secara bertahap lakukan kearah puting susu

5) Pastikan untuk melakukannya pada seluruh payudara

6) Beri perhatian khusus pada area diantaranya payudara dan dibawah lengan termasuk bagian dibawah lengan itu sendiri.

7) Rasakan adanya benjolan atau massa yang tidak lazim dibawah kulit

5. Langkah 5

1) Dengan perlahan ramas puting susu dan perhatikan adanya rabas

2) Jika anda mengeluarkan rabas dari puting susu selama sebulan yang terjadi ketika anda sedang atau tidak melakukan SADARI temuilah dokter anda

3) Ulangi pemeriksaan pada payudara kanan anda

6. Langkah 6
1) Langkah 4 dan 5 harus diulang dengan posisi berbaring

2) Berbaringlah mendatar terlentang lengan kiri anda dibawah kepala anda dan sebuah bantal atau handuk yang dilipat dibawah bahu kiri anda. (Posisi ini akan mendatarkan payudara anda dan memudahkan anda untuk memeriksanya.)

3) Gunakan gerakan sirkuler yang sama seperti yang diuraikan diatas

4) Ulangi pada payudara kanan anda. (Brunner \& Suddarth edisi $8,2011)$.

Pemeriksaan Pada Posisi Berbaring Pemeriksaan posisi berbaring adalah mengulangi langkah 4 dan 5 dengan posisi berbaring. Meraba payudara bertujuan untuk menemukan benjolan abnormal dan adanya guratan-guratan kasar pada kulit payudara. Meraba dilakukan dalam posisi berbaring telentang dengan salah satu tangan dibawah kepala dan meletakan bantalan kecil dibawah bahu. Dalam posisi seperti ini payudara akan tersebar kepermukaan dinding dada sehingga lebih tipis dan lebih mudah untuk menemukan adanya perubahan. Tangan yang dilipat adalah tangan pada sisi payudara yang akan diperiksa. Jika menemukan benjolan yang abnormal yang perlu diperhatikan adalah ukurannya, gerakkan dan ada tidaknya nyeri pada saat perabaan. Lakukan pemeriksaan pada kedua payudara. (Untari, 2012)

\section{Pemeriksaan Di Kamar Mandi}

Periksa payudara anda sewaktu mandi pada waktu tangan dapat meluncur 
dengan mudah diatas kulit yang basah. Denga jari-jari bersusun rata gerakan secara mantap meliputi setiap bagian dari masing-masing payudara. Gunakan tangan kanan untuk memeriksa payudara sebelah kiri dan tangan kiri untuk sebelah kanan. Bagi kebanyakan wanita paling mudah untuk merasakan payudaranya adalah ketika payudara sedang basah dan licin, sehingga paling cocok adalah ketika sedang mandi. (Untari, 2012)

Hasil Pemeriksaan Payudara Sendiri Melihat sendiri perubahan payudara

1. Terjadi pigmentasi kulit payudara (perubahan warna bertambah hitam atau menjadi putih.)

\section{METODOLOGI PENELITIAN}

Dalam peneliti ini penulis menggunakan pendekatan kuantitatif dengan metode deskriptif dengan tujuan untuk mengekspresikan tingkat pengetahuan mahasiswa tentang pemeriksaan payudara sendiri (SADARI) di Prodi Keperawatan Universitas Timor Kampus Atambua.

Populasi dalam peneliti ini adalah semua mahasiswa yang melaksanakan pemeriksaan payudara sendiri di Prodi
2. Perubahan letak puting susu (retraksi puting susu)

3. Perubahan kulit payudara menjadi keriput

4. Puting susu mengeluarkan cairan darah

5. Pergerakan payudara terbatas, artinya saat mnggerakan tangan payudara tidak ikut bergerak

6. Terdapat luka atau ulkus pada payudara

Keperawatan Universitas Timor Kampus Atambua terhitung mulai bulan Januari sampai bulan Februari 2018 dengan 104 orang.

Teknik sampling yang digunakan dalam pengambilan sampel adalah simple random sampling. Kriteria inklusi: mahasiswa Prodi Keperawatan Universitas Timor Kampus Atambua bersedia menjadi responden; Mahasiswa Prodi Keperawatan Universitas Timor Kampus Atambua yang tidak sedang sakit atau ijin; dan Mahasiswa Prodi Keperawatan Universitas Timor Kampus Atambua yang tidak sedang cuti. 


\section{HASIL PENELITIAN}

Penelitian ini dilaksanakan di Prodi Keperawatan Universitas Timor Kampus Atambua selama 2 minggu, dari tanggal 18 April sampai 29 Mei 2018. Dalam penelitian ini peneliti mengambil data dari mahasiswa tingkat I sampai dengan tingkat III dengan distribusinya seperti pada tabel 1 berikut:

\section{Tabel 1}

Gambaran Distribusi Responden Berdasarkan Tingkat I sampai III

\begin{tabular}{lll}
\hline Mahasiswa & Frekuensi & Persentase (\%) \\
\hline Mahasiswa Tingkat I & 11 & 12,0 \\
\hline Mahasiswa Tingkat II & 40 & 43,5 \\
\hline Mahasiswa Tingkat III & 41 & 44,5 \\
\hline Total & $\mathbf{9 2}$ & $\mathbf{1 0 0}$ \\
\hline
\end{tabular}

Berdasarkan tabel 1 partisipasi responden dalam penelitian ini dari mahasiswa tingkat I sebanyak 11 orang (12\%), mahasiswa tingkat II sebanyak 40 orang $(43,5 \%)$ dan responden terbanyak yang berpartisipasi dalam penelitian ini adalah mahasiswa tingkat III dengan jumlah 41orang $(44,5 \%)$.

Gambaran Tingkat Pengetahuan Mahasiswa Tentang Pemeriksaan payudara sendiri di Prodi Keperawatan Universitas Timor Kampus Atambua.

1. Tingkat pengetahuan mahasiswa tentang pemeriksaan payudara sendiri dalam hal Tahu (Know)

Tabel. 2

Distribusi Frekuensi Tingkat Pengetahuan Mahasiswa Dalam Hal Tahu (Know)

\begin{tabular}{llll}
\hline Variabel & Kategori & Frekuensi & Persentase (\%) \\
\hline \multirow{3}{*}{ Tahu } & Kurang & 1 & 1,1 \\
& Cukup & 0 & 0,0 \\
& Baik & 91 & 98,9 \\
\hline & Total & 92 & 100 \\
\hline
\end{tabular}

Sumber: Data Primer 2018

Berdasarkan tabel. 2, dari 92 responden yang diteliti diketahui bahwa tingkat pengetahuan mahasiswa tentang pemeriksaan payudara sendiri dalam hal tahu (Know) dengan kategori baik sebanyak 91 responden $(98,9 \%)$ sisanya dalam kategori kurang yaitu sebanyak 1 responden $(1,1 \%)$. Sedangkan kategori cukup pada tingkat pengetahuan ini yaitu 0 responden $(0,0 \%)$.

2. Tingkat pengetahuan Mahasiswa tentang pemeriksaan payudara sendiri dalam hal Memahami (Comprehension) 
Tabel. 3

Distribusi Frekuensi Tingkat Pengetahuan Mahasiswa Dalam Hal memahami (Comprehension)

\begin{tabular}{llll}
\hline Variabel & Kategori & Frekuensi & Persentase (\%) \\
\hline \multirow{3}{*}{ Memahami } & Kurang & 3 & 3,3 \\
& Cukup & 8 & 8,7 \\
& Baik & 81 & 88,0 \\
\hline \multicolumn{2}{l}{ Total } & 92 & 100 \\
\hline
\end{tabular}

Berdasarkan pada tabel 3, dari 92 responden diketahui bahwa tingkat pengetahuan mahasiswa tentang pemeriksaan payudara sendiri dalam hal memahami (comprehension) dengan kategori baik yaitu sebanyak 81 responden $(88,0 \%)$, sedangkan untuk kategori cukup sebanyak 8 responden $(8,7 \%)$ dan untuk kategori kurang sebanyak 3 responden $(3,3 \%)$.

3. Tingkat pengetahuan Mahasiswa tentang pemeriksaan payudara sendiri dalam hal Penerapan (aplication)

Tabel. 6

Distribusi Frekuensi Tingkat Pengetahuan Mahasiswa Dalam Hal Penerapan (Aplication)

\begin{tabular}{llll}
\hline Variabel & Kategori & Frekuensi & Persentase (\%) \\
\hline \multirow{3}{*}{ Aplikasi } & Kurang & 0 & 0,0 \\
& Cukup & 7 & 7,6 \\
& Baik & 85 & 92,4 \\
\hline & Total & 92 & 100
\end{tabular}

Sumber: Data Primer 2018

Berdasarkan tabel. 6, dari 92 responden dapat di simpulkan bahwa tingkat pengetahuan mahasiswa tentang pemeriksaan payudara sendiri dalam hal penerapan (Aplication) dengan kategori baik yaitu sebanyak 85responden $(92,4 \%)$ dan dalam kategori cukup adalah dengan jumlah 7 (7,6\%). Sedangkan dalam kategori kurang adalah 0 responden $(0,0 \%)$.

4. Tingkat pengetahuan Mahasiswa tentang pemeriksaan payudara sendiri dalam hal Analisis (Analysis)

Tabel. 7

Distribusi Frekuensi Tingkat Pengetahuan Mahasiswa Dalam Hal Analisis (Analysis)

\begin{tabular}{llll}
\hline Ariabel & Kategori & Frekuensi & Persentase (\%) \\
\hline \multirow{3}{*}{ Aplikasi } & Kurang & 6 & 6,5 \\
& Cukup & 0 & 0,0 \\
& Baik & 86 & 93,5 \\
\hline \multicolumn{2}{c}{ Total } & 92 & 100 \\
\hline Sumber: Data Primer 2018 & &
\end{tabular}


Berdasarkan tabel. 7 dapat di ketahui bahwa dari 92 responden yang diteliti tingkat pengetahuan mahasiswa tentang pemeriksaan payudara sendiri dalam hal analisis (analysis) dengan kategori baik yaitu sebanyak 86 responden $(93,5 \%)$ dan dalam kategori kurang adalah sebanyak 6 responden $(6,5 \%)$. Sedangkan dalam kategori kurang yaitu sebanyak 0 responden $(0,0 \%)$.

5. Tingkat Pengetahuan Mahasiswa Prodi Keperawatan Universitas Timor Kampus Atambua Tentang Pemeriksaan Payudara Sendiri Secara Umum

Tabel. 8

Distribusi Frekuensi Tingkat Pengetahuan Mahasiswa Prodi Keperawatan Universitas Timor kampus Atambua Tentang Pemeriksaan Payudara Sendiri

\begin{tabular}{|c|c|c|c|c|}
\hline Variabel & & Kategori & Frekuensi & Persentase $(\%)$ \\
\hline \multirow{3}{*}{$\begin{array}{l}\text { Tingkat } \\
\text { Mahasiswa }\end{array}$} & \multirow{3}{*}{ Pengetahuan } & Kurang & $\overline{0}$ & 0,00 \\
\hline & & Cukup & 3 & 3 \\
\hline & & Baik & 89 & 97 \\
\hline & & Total & 92 & 100 \\
\hline
\end{tabular}

Sumber: Data Primer 2018

Dari tabel. 8 di atas dapat di ketahui bahwa dari 92 responden yang diteliti tingkat pengetahuan mahasiswa Prodi Keperawatan Universitas Timor Kampus Atambua tentang pemeriksaan payudara sendiri dalam kategori baik yaitu sebanyak 89 responden (97\%) dan dalam kategori cukup adalah sebanyak 3 responden (3\%). Sedangkan dalam kategori kurang yaitu sebanyak 0 responden $(0,0 \%)$. 


\section{PEMBAHASAN}

Secara umum penelitian ini bertujuan untuk mengetahui gambaran tingkat pengetahuan mahasiswa tentang pemeriksaan payudara sendiridi Prodi Keperawatan Universitas Timor Kampus Atambua. Peneliti secara khusus juga meneliti tingkat pengetahuan mahasiswa yang dikelompokan berdasarkan tingkat pengetahuan dalam hal Tahu (Know), Memahami (Comprehension), Penerapan (Aplication) dan Analisis (Analysis). Berikut ini adalah pembahasan setiap tingkat pengetahuan berdasarkan hasil penelitian

Tingkat Pengetahuan Mahasiswa Prodi Keperawatan Universitas Timor Kampus Atambua Tentang Pemeriksaan Payudara Sendiri Secara Umum

Hasil Penelitian menunjukkan bahwa dari 92 responden yang diteliti, dapat diketahui bahwa tingkat pengetahuan mahasiswa Prodi Keperawatan Universitas Timor Kampus Atambua tentang pemeriksaan payudara sendiri dalam kategori baik yaitu sebanyak 89 responden (97\%), cukup sebanyak 3 responden (3\%) dan kategori kurang itu sebanyak 0 responden $(0,0 \%)$.

Sebagai perbandingan dari hasil penelitian ini peneliti juga menganalisa dan membandingkannya dengan hasil penelitian yang dilakukan oleh empat orang peneliti terdahulu di empat lokasi yang berbeda untuk mengetahui tingkat pengetahuan secara umum dalam hal pemeriksaan payudara sendiri. Pertama, pada penelitian yang dilakukan oleh Etri Lolita Andika Putri, Imelda Ingir Ladjar dan Dini Rahmayani di SMP
Anggrek Banjarmasin hasilnya menunjukkan bahwa sebagian besar responden memiliki pengetahuan yang kurang tentang tingkat pengetahuan pemeriksaan payudara sendiri (SADARI) yaitu sebanyak 42 responden $(60 \%)$ dari 70 responden yang diteliti.

Kedua, pada penelitian dalam hal tingkat pengetahuan remaja putri Tentang periksa payudara sendiri (sadari) yang dilakukan oleh Tita Restu Yuliasri dan Ria Armalina di Dusun Gemblangan Timbulharjo Sewon Bantul Yogyakarta hasil penelitiannya diketahui bahwa dari 21 responden yang diteliti sebagian besar responden dengan tingkat pengetahuan remaja putri tentang SADARI baik yaitu sebanyak 18 responden $(85,7 \%)$.

Ketiga, penelitian yang dilakukan oleh Mardiana di SMA Negeri 1 Kabupaten Tuban hasilnya menunjukan bahwa dari 92 responden yang diteliti terdapat sebanyak 73 responden $(79,35 \%)$ yang memiliki tingkat pengetahuan dengan kategori baik.

Keempat, pada penelitian yang dilakukan oleh Harnianti di Fakultas Kesehatan Kasyarakat (FKM) Universitas Halu Oleo hasilnya menunjukkan bahwa dari 83 responden yang di teliti dalam upaya pemeriksaan payudara sendiri (SADARI) terdapat 79 responden $(95,2 \%)$ memiliki tingkat pengetahuan dengan kategori baik.

Menurut Soekidjo Notoatmodjo (2003) pengetahuan merupakan hasil "Tahu" dan ini terjadi setelah orang melakukan pengindraan terhadap suatu objek tertentu. Pengindraan terjadi melalui indra manusia yakni indra penglihatan, pendengaran, penciuman, rasa dan raba. Sebagian besar pengetahuan 
manusia diperoleh melalui mata dan telinga. Faktor yang mempengaruhi pengetahuan antara lain adalah umur dan pendidikan.

Hasil penelitian dari kelima peneliti di atas menunjukkan bahwa penelitian yang di lakukan di SMP Anggrek sebagian besar responden memiliki pengetahuan yang kurang tentang tingkat pengetahuan pemeriksaan payudara sendiri (SADARI) yaitu sebanyak 42 responden $(60 \%)$, hasil penelitian pada remaja di Dusun Gemblangan Timbulharjo Sewon Bantul Yogyakarta hasil penelitiannya diketahui bahwa dari 21 responden yang diteliti sebagian besar responden dengan tingkat pengetahuan remaja putri tentang SADARI baik yaitu sebanyak 18 responden $(85,7 \%)$, hasil penelitian pada SMA Negeri I adalah 75,35\%. Sedangkan pada Prodi Keperawatan Universitas Timor Kampus Atambua dan Fakultas Kesehatan Masyarakat Universitas Halo Oleo tingkat pengetahuan dalam hal SADARI adalah $97 \%$ dan 95,2\%. Hal ini dapat disimpulkan bahwa semakin tinggi tingkat pedidikan lebih espesifik ke pendidikan kesehatan akan semakin baik tingkat pengetahuan seseorang dalam hal pemeriksaan Payudara sendiri.

Hal lain yang turut meningkatkan tingkat pengetahuan tentang SADARI adalah sering berpartisipasi dalam penyuluhan yang diadakan oleh petugas kesehatan di daerah atau di sekolah, serta dapat mengakses informasi dari sumber lain seperti radio, televisi, surat kabar, majalah dan berbagai sumber informasi yang lainya. Selain itu mahasiswa tersebut saat ini sudah mempelajari anatomi fisiologi, sering mendengarkan materi tentang kesehatan dan sering berpartisipasi dalam penyuluhan yang diadakan oleh petugas kesehatan di kampus serta kegiatan dann mengakses informasi dari sumber lain seperti radio, televisi, surat kabar, majalah dan berbagai sumber informasi yang lainya.

Hasil penelitian ini menunjukan bahwa mahasiswa Prodi keperawatan Universitas Timor kampus Atambua memiliki tingkat pengetahuan yang baik dalam hal pemeriksaan payudara sendiri. Hal ini menunjukan bahwa mahasiswa memiliki kemampuan yang baik dalam mengingat kembali materi tentang SADARI yang telah dipelajari, mampu dalam menjelaskan, menginterprestasikan dan memberikan contoh dan dengan baik menerapkan pemeriksaaan payudara sendiri yang tela dipelajadi atau didapatnya dari berbagai sumber informasi, serta mahasiswa dengan baik dapat membedakan atau memisahkan, mengelompokan, dan membuat diagram (bagan) terhadap pengetahuan tentang pemeriksaan payudara sendiri.

\section{Tingkat Pengetahuan Mahasiswa Tentang Pemeriksaan Payudara Sendiri Dalam Hal Tahu (Know)}

Berdasarkan hasil penelitian menunjukan bahwa dari 92 responden yang diteliti diketahui bahwa tingkat pengetahuan mahasiswa tentang pemeriksaan payudara sendiri dalam hal tahu (Know) dengan kategori baik sebanyak 91 responden $(98,9 \%)$ sisanya dalam kategori kurang yaitu sebanyak 1 responden $(1,1 \%)$. Sedangkan kategori cukup pada tingkat pengetahuan ini yaitu 0 responden $(0,0 \%)$. Tahu diartikan sebagai kemampuan masyarakat 
mengingat atau recall (memanggil) kembali memori atau materi yang telah dipelajari berkaitan dengan pencegahan kanker payudara (Notoatmodjo 2010 dalam Untari). Dengan demikian dari hasil penelitian menunjukkan bahwa Mahasiswa Prodi Keperawatan Unimor Kampus Atambua memiliki kemampuan yang baik dalam mengingat atau memangil kembali memori atau materi yang telah dipelajari dalam hal ini materi tentang SADARI.

\section{Tingkat Pengetahuan Mahasiswa Tentang Pemeriksaan Payudara Sendiri Dalam Hal Memahami(Comprehension)}

Hasil penelitian menunjukkan bahwa pada tingkat ini dari 92 responden diteliti diketahui bahwa tingkat pengetahuan mahasiswa tentang pemeriksaan payudara sendiri dalam hal memahami (comprehension) dengan kategori baik yaitu sebanyak 81 responden $(88,0 \%)$, sedangkan untuk kategori cukup sebanyak 8 responden $(8,7 \%)$ dan untuk kategori kurang yaitu dengan jumlah 3 responden $(3,3 \%)$.

Memahami dapat diartikan sebagai suatu keadaan dimana seseorang mampu menjelaskan dan menginterprestasikan dengan benar tentang objek yang diketahui misalnya orang yang memahami SADARI bukan hanya sekedar menjelaskan tetapi harus dapat memberikan contoh dan menyimpulkan.

Berdasarkan pada hasil penelitian tersebut dapat disimpulkan bahwa tingkat pemahaman mahasiswa adalah baik. Dengan kata lain Mahasiswa Prodi Keperawatan Atambua mampu dengan baik dalam menjelaskan, menginterprestasikan dan memberikan contoh mengenai SADARI.

\section{Tingkat Pengetahuan Mahasiswa Tentang Pemeriksaan Payudara Sendiri Dalam Hal Aplikasi (Aplication)}

Dari hasil penelitian menunjukan bahwa pada tingkat penerpan (Aplication) dari 92 responden yang diteliti dapat di simpulkan bahwa tingkat pengetahuan mahasiswa tentang pemeriksaan payudara sendiri dalam hal penerapan (Aplication) dengan kategori baik yaitu sebanyak 85 responden $(92,4 \%)$ dan dalam kategori cukup adalah dengan jumlah 7 (7,6\%). Sedangkan dalam kategori kurang adalah 0 responden $(0,0 \%)$.

Aplikasi (Aplication) diartikan sebagai kemampuan untuk menggunakan materi yang telah dipelajari pada situasi atau kondisi yang sebenarnya. Misalnya seseorang yang telah paham tentang pemeriksaan payudara sendiri (SADARI) ia harus membuat perencanaan pencegahan kanker payudara ditempat ia tinggal atau dimana saja.

Berdasarkan pada hasil penelitian dapat dipahami bahwa mahasiswa Prodi Keperawatan Universitas Timor Kampus Atambua dengan baik menerapkan pemeriksaaan payudara sendiri yang tela dipelajadi atau didapatnya dari berbagai sumber informasi.

\section{Tingkat Pengetahuan Mahasiswa Tentang Pemeriksaan Payudara Sendiri Dalam Hal Analisis (Analysis)}

Hasil penelitian diketahui bahwa dari 92 responden yang diteliti tingkat pengetahuan mahasiswa 
tentang pemeriksaan payudara sendiri dalam hal analisis (analysis) dengan kategori baik yaitu sebanyak 86 responden $(93,5 \%)$ dan dalam kategori kurang adalah sebanyak 6 responden $(6,5 \%)$. Sedangkan dalam kategori kurang yaitu sebanyak 0 responden $(0,0 \%)$.

Analisis (Analysis) adalah suatu kemampuan untuk menjabarkan atau memisahkan kemudian mencari hubungan antara komponen-komponen yang terdapat dalam suatu masalah atau objek yang diketahui indikasi bahwa pengetahuan seseorang itu sudah sampai pada tingkat analisis adalah apabila orang tersebut telah dapat membedakan atau memisahkan, mengelompokan membuat diagram (bagan) terhadap pengetahuan atau objek tersebut.

Dengan demikian berdasarkan hasil tersebut dapat dipahami bahwa tingkat analisis mahasiswa Prodi Keperawatan Universitas Timor Kampus Atambua adalah baik. Dengan kata lain, mahasiswa dengan baik dapat membedakan atau memisahkan, mengelompokan, dan membuat diagram (bagan) terhadap pengetahuan tentang pemeriksaan payudara sendiri.

\section{KESIMPULAN}

Berdasarkan hasil penelitian di atas tentang Gambaran tingkat pengetahuan mahasiswa prodi keperawatan Universitas Timor Kampus atambua tentang pemeriksaan payudara sendiri di Prodi Keperawatan Universitas Timor Kampus Atambua dari 92 responden yang di teliti dapat disimpulkan sebagai berikut :

1. Secara umum tingkat pengetahuan mahasiswa Prodi Keperawatan Universitas Timor Kampus
Atambua tentang pemeriksaan payudara sendiri adalah baik (97\%).

2. Gambaran Tingkat pengetahuan Mahasiswa Prodi keperawatan Universitas Timor kampus Atambua dalam hal tahu (know)adalah baik $(98,9 \%)$

3. Gambaran Tingkat pengetahuan Mahasiswa Prodi keperawatan Universitas Timor kampus Atambua dalam hal memahami (Comprehension) adalah baik $(88,0 \%)$

4. Gambaran Tingkat pengetahuan Mahasiswa Prodi keperawatan Universitas Timor kampus Atambua dalam hal penerapan (Aplication) adalah baik $(92,4 \%)$

5. Gambaran Tingkat pengetahuan Mahasiswa Prodi keperawatan Universitas Timor kampus Atambua dalam hal analisis (Analysis) adalah baik $(93,5 \%)$.

\section{SARAN}

1. Bagi Mahasiswa

Diharapkan mahasiswa dapat mempertahankan dan meningkatkan pengetahuan tentang pemeriksaan payudara sendiri sehingga dapat terhindar dari bebagai macam penyakit yang berkaitan dengan payudara.

2. Bagi Institusi

Diharapkan hasil penelitian ini dapat menambah sumber referensi penelitian khususnya tingkat pengetahuan mahasiswa tentang pemeriksaan payudara sendiri sehingga dapat memperluas pengetahuan 
mahasiswa dalam penelitian serupa.

3. Pagi Peneliti Selanjutnya

Diharapkan bagi peneliti selanjutnya melakukan penelitian lebih mendalam mengenai faktor - faktor yang mempengaruhi tingkat pengetahuan mahasiswa tentang pemeriksaan payudara sendiri.

\section{DAFTAR PUSTAKA}

Anugrahini, C. 2016. "Panduan Penyusunan Karya Tulis Ilmiah : Studi Kasus DIII Keperawatan.

Brunner \& suddarth, 2014, "Keperawatan MedikalBedah. Jakarta : EGC

Coad. 2006. Anatomi dan fisiologi untuk bidan. Jakarta : EGC

Handayani, 2013, "Perilaku Mahasiswa Tentang Periksa Payudara Sendiri (SADARI),Universitas Stikes Kusuma Surakarta.

Anggriani, 2017, "Gambaran Tingkat Pengetahuan Remaja Putri Tentang SADARI, Stikes Jenderal Achmad yani Yogyakarta.

Muttaqin, Arif, 2012, "Pengkajian Keperawatan Aplikasi Pada Praktik Klinik. Jakarta : Salemba Medika.

Riskan, 2012, "Kesan awal dengan pemeriksaan payudara sendiri. Di upload pada tanggal 25 januari 2018 pukul:16:00
Saptaputra dkk, 2012," Studi Perilaku Pemeriksaan Payudara Sendiri (SADARI) Pada Mahasiswa, Universitas Halu Oleo.

Untari, 2012," Gambaran Pengetahuan Remaja Putri Tentang Pemeriksaan Payudara Sendiri (SADARI), Universitas Indonesia.

Wardhani, 2017, "Kesehatan Masyarakat", Universitas FKM UNDIP Semarang. 